\title{
Pengaruh Kadar Protein Susu Formula terhadap Status Gizi Lebih Usia 3 hingga 5 bulan
}

Noor Anggrainy Retnowati, Endang Dewi Lestari, Ganung Harsono

Departemen Ilmu Kesehatan Anak Fakultas Kedokteran Universitas Sebelas Maret, Surakarta

Latar belakang. Ibu berkerja dan merasa ASI tidak mencukupi kebutuhan menjadi alasan di kalangan masyarakarat pemberiaan susu formula difortifikasi zat besi sebagai pengganti ASI. Data statistik Surakarta, prevalensi wanita bekerja meningkat dan mempengaruhi pemberiaan ASI eksklusif. Pemberiaan protein awal kehidupan yang berlebih berdampak gizi lebih.

Tujuan. Untuk mengetahui pengaruh kadar protein terhadap status gizi.

Metode. Penelitian merupakan studi potong lintang. Subjek berusia 3 sampai 5 bulan di Posyandu Kecamatan Banjarsari, Laweyan dan Jebres antara April hingga Oktober 2018. Hubungan antar variabel dianalisis menggunakan uji chi square dan uji regresi logistik multivariat.

Hasil. Uji regresi logistic multivariat menunjukkan kadar protein, frekuensi pemberiaan $>12 \mathrm{kali} /$ hari dan ukuran botol $>180 \mathrm{ml}$ berpengaruh terhadap gizi lebih.

Kesimpulan. Status gizi lebih pada usia 3 hingga 5 bulan dipengaruhi kadar protein, frekuensi pemberiaan susu, dan ukuran botol. Sari Pediatri 2019;21(4):226-30

Kata kunci: protein, status gizi, anak

\section{The Effect of Formula Milk Protein Levels on Nutritional Status Over 3 to 5 months}

Noor Anggrainy Retnowati, Endang Dewi Lestari, Ganung Harsono

Background. Nowadays, fortified iron formula milk is commonly used as a substitute for breastmilk because many mother on leave their babies for working and some mothers feel that their breastmilk is not sufficient. Based on Surakarta statistical data, the prevalence of working women affects in exclusive breastfeeding. Protein intake is associated with more rapid weight gain during infancy, which later may cause overweight.

Objective. To determine the relationship between protein level and the nutritional status.

Methods. This cross sectional study was conducted in aged 3 to 5 months in maternal and child health centers in Banjarsari, Laweyan and Jebres between April and October 2018. Relationship between variables was analyzed with Chi Square and multivariat logistic regression test.

Result. Multivariat logistic regression analysis revealed that higher protein, frequency of formula feeding $>12$ times/day, bottle size $>180 \mathrm{ml}$ were associated with overweight.

Conclusion. Overweight in children aged 3 to 5 months is associated with protein intake, frequency of formula feeding and bottle size. Sari Pediatri 2019;21(4):226-30

Key words: protein, nutritional status, children

Alamat korespondensi: Noor Anggrainy Retnowati. Departemen Ilmu Kesehatan Anak Fakultas Kedokteran Universitas Sebelas Maret, Surakarta. Email: nooranggrainy@gmail.com 
Noor Anggrainy Retnowati dkk: Pengaruh kadar protein susu formula terhadap status gizi lebih usia 3 hingga 5 bulan

$\mathrm{A}$ ir susu ibu (ASI) merupakan makanan tunggal yang terbaik untuk bayi dan setiap bayi memiliki hak mendapatkan ASI. Keadaan ASI tertera dalam WHO dan UNICEF (2009) sebagai Acceptable Medical Reasons for Breast-Milk Substitutes. Apabila ASI tidak dapat diberikan, susu formula yang difortifikasi dengan zat besi menjadi pilihan ${ }^{1,2}$

Pada kehidupan sehari-hari didapatkan beberapa bayi yang mengonsumsi susu formula yang difortifikasi zat besi sebagai pengganti ASI dikarenakan beberapa hal, seperti ibu bekerja dan merasa ASI tidak mencukupi kebutuhan bayi. Dari data statistik Surakarta tahun 2010 didapatkan 118.765 wanita berusia produktif bekerja. Pemberiaan ASI ekslusif hingga usia 6 bulan hanya $15,6 \% .{ }^{3}$ Dari data tersebut, ibu bekerja berhubungan dengan rendahnya prevalensi pemberiaan ASI eksklusif.

Pemberiaan protein yang berlebih pada awal kehidupan akan berdampak pada peningkatan berat badan yang meningkatkan overweight dan obesitas kemudian hari. ${ }^{4}$ Densitas energi susu hewani $(1,8$ $3 \mathrm{gr} / 100 \mathrm{kkal}$ atau $1,45-1,6 \mathrm{~g} / \mathrm{dL})$ lebih besar dibandingkan ASI (1,5 g/100 kkal atau $650 \mathrm{kkal} / \mathrm{L})$ yang akan berakibat risiko penambahan berat badan berlebih yang berdampak overweight dan obesitas. ${ }^{5}$

Di beberapa negara benua Eropa didapatkan pemberiaan formula protein 2,05 gram/100 kkal pada usia bayi akan meningkatkan berat badan 1,92 kali kemudian hari saat usia 6 tahun dengan dibandingkan pemberiaan formula protein $1,25 \mathrm{gram} / 100 \mathrm{kkal}{ }^{6}$ Penelitian peranan protein susu formula terhadap gizi lebih pada usia kurang dari 6 bulan di Indonesia masih terbatas. Hal ini mendorong penulis meneliti hal tersebut.

\section{Metode}

Penelitian ini adalah penelitian observasional analitik dengan studi potong lintang yang dilakukan di Posyandu wilayah kerja Kecamatan Banjarsari, Laweyan dan Jebres, Surakarta dari bulan April sampai dengan Oktober 2018. Cara pengambilan sampel dilakukan secara konsekutif yang memenuhi kriteria inklusi serta eksklusi. Sebelumnya, lembar persetujuan mengikuti penelitian ditandatangani orangtua/wali . Kriteria inklusi, antara lain, usia tiga hingga lima bulan, konsumsi susu formula dengan satu merk dagang minimal merk dagang yang sama selama satu bulan.
Kriteria eksklusi, antara lain, bayi lahir kurang dari 37 minggu, berat badan lahir kurang dari 2500 gram dan lebih dari 3500 gram, menderita sindrom Cushing, lesi hipotalamus didapat dan obesitas dengan wajah dismorfik, penyaki kronis seperti penyakit jantung bawaan talasemia, tuberkulosis paru dan keganasaan.

Berdasarkan perhitungan dan tabel besar sampel untuk analitik korelatif ordinal diperoleh jumlah sampel yang diperlukan adalah 65. Kadar protein di susu formula diperoleh dari data kandungan protein yang tertera pada katalog kandungan nilai gizi pada susu formula dengan cara kuesinoner yang diisi oleh orangtua subyek. Kemudian dikelompokkan menjadi normal (kadar protein 1,8-2 gram/100 kkal) dan tinggi (kadar protein lebih dari 2 gram/100 kkal). Penentuan status gizi secara pengukuran antropometri $\mathrm{BB} / \mathrm{TB}$ WHO 2006 dan IMT WHO 2006. Pengelompokkan subyek dengan gizi baik dengan hasil Z-Score -2SD hingga +2 SD dan gizi lebih jika IMT lebih dari +2 .

Hubungan bivariat antara kedua variabel dianalisis dengan uji chi square menggunakan program SPSS. Hubungan multivariat antar variabel menggunakan analisis regresi logistik multivariat. Hasil disebut bermakna jika $p \leq 0,05^{7}$. Penelitian ini sudah memperoleh kelaikan etik dan dinyatakan layak etik oleh Komisi Etik Penelitian Kesehatan RS Dr. Moewardi/Fakultas Kedokteran Universitas Sebelas Maret dan Dinas Kota Surakarta

\section{Hasil}

Penelitian ini dilakukan pada 174 anak usia tiga hingga lima bulan di Posyandu wilayah kerja Kecamatan Banjarsari, Laweyan dan Jebres, Surakarta antara bulan April hingga Oktober 2018. Karakteristik demografi subjek penelitian tertera pada Tabel 1.

Berdasarkan tabel 1 diketahui prevalensi terbanyak adalah subyek berusia 4 bulan (35,6\%). Jenis kelamin terbanyak adalah laki-laki (62,3\%). Kadar protein, lemak, dan karbohidrat susu formula yang dikonsumsi subyek sebagian besar sesuai dengan aturan Codex alimentarius dengan kadar normal protein $36,2 \%$, lemak $69,5 \%$, dan karbohidrat $69,5 \%$. Pada penelitian ini mayoritas subyek diberikan susu formula dengan frekuensi kurang 12 kali $(72,4 \%)$. Penelitian ini mayoritas subyek diberikan botol susu ukuran $<180$ $\mathrm{mL}(89,7 \%)$. Subyek pada penelitian mayoritas dengan status gizi normal $(69,0 \%)$. 
Tabel 1. Karakteristik demografi subjek penelitian

\begin{tabular}{|c|c|c|}
\hline Variabel & $\mathrm{f}$ & $\%$ \\
\hline \multicolumn{3}{|l|}{ Usia (bulan) } \\
\hline 3 & 58 & 33,3 \\
\hline 4 & 62 & 35,6 \\
\hline 5 & 54 & 31,0 \\
\hline \multicolumn{3}{|l|}{ Jenis kelamin } \\
\hline Perempuan & 66 & 37,9 \\
\hline Laki-laki & 108 & 62,1 \\
\hline \multicolumn{3}{|l|}{ Protein } \\
\hline Tinggi & 57 & 32,8 \\
\hline Normal & 117 & 36,2 \\
\hline \multicolumn{3}{|l|}{ Lemak } \\
\hline Normal & 121 & 69,5 \\
\hline Kurang $(<4,4)$ & 53 & 30,5 \\
\hline \multicolumn{3}{|l|}{ Karbohidrat } \\
\hline Normal & 121 & 69,5 \\
\hline Kurang $(<9)$ & 53 & 30,5 \\
\hline \multicolumn{3}{|c|}{ Frekuensi_pemberian } \\
\hline$>12$ kali & 48 & 27,6 \\
\hline$\leq 12$ kali & 126 & 72,4 \\
\hline \multicolumn{3}{|l|}{ Ukuran botol (mL) } \\
\hline$>180$ & 18 & 10,3 \\
\hline$<180$ & 156 & 89,7 \\
\hline \multicolumn{3}{|l|}{ Status gizi } \\
\hline Gizi lebih & 54 & 31,0 \\
\hline Gizi normal & 120 & 69 \\
\hline
\end{tabular}

Berdasarkan tabel 2 diketahui hubungan kadar tinggi protein berisiko 4 kali terjadinya kejadian status gizi lebih didapatkan hasil $(\mathrm{p}=<0,001)$. Hubungan frekuensi pemberiaan susu formula lebih 12 kali dalam sehari meningkatkan dengan kejadian status gizi lebih $(\mathrm{p}=<0,001)$. Hubungan ukuran botol susu $>180 \mathrm{ml}$ meningkatkan kejadian status gizi lebih $(\mathrm{p}=<0,001)$.

Dalam analisis multivariat pada Tabel 3 diketahui pemberiaan susu dengan kadar tinggi protein dapat berisiko 15 kali terjadinya status gizi lebih $(\mathrm{p}<0,005)$. Subyek yang diberikan susu formula dengan frekuensi $>12$ kali per hari berisiko terjadinya status gizi lebih $(\mathrm{p}<0,001)$.

\section{Pembahasan}

Asupan protein selama awal masa kehidupan memengaruhi peningkatan berat badan dini. Pada penilitian ini didapatkan uji bivariat kadar tinggi protein pada susu formula memiliki risiko terjadi status gizi lebih 4 kali dibandingkan kadar normal protein. Pada uji multivariat, kadar tingi protein pada susu formula memiliki risiko 15 kali terjadinya gizi lebih. Hal tersebut didukung dengan penelitian Weber ${ }^{8}$ yang melaporkan bahwa anak yang diberikan tinggi protein secara bermakna akan meningkatkan Indeks massa tubuh (IMT) 2 kali dibandingkan dengan anak yang diberikan rendah protein. Pemberian susu formula tinggi protein yang diberikan saat lahir akan berisiko obesitas pada usia 6 tahun sebanyak 2 kali dibandingkan pemberiaan susu formula rendah protein. ${ }^{9}$ Di Cina, peningkatan IMT didapatkan pada bayi tiap bulan yang akan memprediksi risiko terjadinya obesitas pada usia 2 tahun. ${ }^{10}$ Kelebihan berat badan hingga usia 2 tahun menjadi prediktor obesitas kemudian hari. ${ }^{11}$ Kadar protein yang tinggi pada susu formula menstimulasi insulin dan IGF-1 yang berdampak pertumbuhan pada berat badan. ${ }^{12}$

Pada penelitian ini didapatkan data bahwa jenis kelamin perempuan terlindungi dari terjadinya status gizi lebih dibandingkan jenis kelamin lelaki. Hal tersebut sesuai bahwa interpretasi IMT tergantung dengan jenis kelamin dikarenakan anak lelaki dan perempuan memiliki lemak tubuh yang berbeda. ${ }^{13}$

Salah satu factor yang memengaruhi status gizi lebih adalah frekuensi pemberiaan susu. Pemberian susu formula sebanyak 15 hingga 24 kali per hari berhubungan dengan peningkatan gizi lebih. Pada penelitian ini, frekuensi pemberian susu lebih dari 12 kali memiliki risiko 15 kali terjadi status gizi lebih. Penelitian ini didukung oleh penelitian sebelumnya. Puji $\mathrm{dkk}^{14}$ melaporkan bahwa pemberiaan susu formula pada usia 0 hingga 6 bulan dengan frekuensi lebih dari 20 kali berhubungan dengan peningkatan kejadian status gizi lebih.

Ukuran botol susu juga memengaruhi status gizi lebih. Pada penelitian ini secara uji bivariat, ukuran bukuran botol $>180 \mathrm{ml}$ memiliki risiko 54 kali terjadinya status gizi lebih. Hal tersebut didukung oleh penelitan sebelumnya di benua Amerika. Charies $\mathrm{dkk}^{15}$ melaporkan bahwa, pemberian susu formula dengan botol ukuran besar $(>6 \mathrm{oz}=>180 \mathrm{ml})$ berkorelasi 0,21 kali terjadinya peningkatan berat badan.

Kelemahan penelitian ini adalah faktor perancu yang hanya dapat dikendalikan, yaitu ukuran botol susu dan frekuensi pemberiaan susu formula. Di lapangan, faktor pencetus yang sangat dimungkinkan adalah faktor pemberiaan susu yang tidak sesuai 
Tabel 2. Hasil uji bivariat

\begin{tabular}{|c|c|c|c|c|c|}
\hline \multirow[b]{2}{*}{ Variabel } & \multirow[b]{2}{*}{$\begin{array}{c}\text { Total } \\
(\mathrm{n}=174)\end{array}$} & \multicolumn{2}{|c|}{ Status_gizi } & \multirow[b]{2}{*}{ OR (95\%CI) } & \multirow[b]{2}{*}{ P } \\
\hline & & $\begin{array}{l}\text { Gizi lebih } \\
(\mathrm{n}=54)\end{array}$ & $\begin{array}{l}\text { Gizi normal } \\
\quad(n=120)\end{array}$ & & \\
\hline \multicolumn{6}{|l|}{ Jenis kelamin } \\
\hline Perempuan & 66 & $18(27,3 \%)$ & $48(72,7 \%)$ & $0,750(0,382-1,471)$ & 0,402 \\
\hline Laki-laki & 108 & $36(33,3 \%)$ & $72(66,7 \%)$ & Ref & Ref \\
\hline \multicolumn{6}{|l|}{ Protein } \\
\hline Tinggi & 57 & $30(52,6 \%)$ & $27(47,4 \%)$ & $4.306(2.166-8.557)$ & $<0,001$ \\
\hline Normal & 117 & $24(20.5 \%)$ & $93(79.5 \%)$ & Ref & Ref \\
\hline \multicolumn{6}{|l|}{ Lemak } \\
\hline Normal & 121 & $39(32,2 \%)$ & $82(67,8 \%)$ & $1,205(0,593-2,448)$ & 0,606 \\
\hline Kurang & 53 & $15(28,3 \%)$ & $38(71,7 \%)$ & Ref & Ref \\
\hline \multicolumn{6}{|l|}{ Karbohidrat } \\
\hline Normal & 121 & $39(32,2 \%)$ & $82(67,8 \%)$ & $1,205(0,593-2,448)$ & 0,606 \\
\hline Kurang & 53 & $15(28,3 \%)$ & $38(71,7 \%)$ & Ref & Ref \\
\hline \multicolumn{6}{|c|}{ Frekuensi_Pemberian } \\
\hline$>12 \mathrm{kali}$ & 48 & $46(95,8 \%)$ & $2(4,2 \%)$ & $339,250(69,424-1657,781)$ & $<0,001$ \\
\hline$\leq 12 \mathrm{kali}$ & 126 & $8(6,3 \%)$ & $118(93,7 \%)$ & Ref & Ref \\
\hline \multicolumn{6}{|l|}{ Ukuran botol } \\
\hline$>180 \mathrm{ml}$ & 18 & $17(94,4 \%)$ & $1(5,6 \%)$ & $54,676(7,037-424,822)$ & $<0,001$ \\
\hline$<180 \mathrm{ml}$ & 156 & $37(23,7 \%)$ & $119(76,3 \%)$ & Ref & Ref \\
\hline
\end{tabular}

Tabel 3. Hasil uji analisis multivariat

\begin{tabular}{|c|c|c|c|c|c|}
\hline & \multirow{2}{*}{ Total } & \multicolumn{2}{|c|}{ Status_gizi } & \multirow{2}{*}{ OR } & \multirow{2}{*}{$\mathrm{P}$} \\
\hline & & Gizi lebih & Gizi normal & & \\
\hline \multicolumn{6}{|l|}{ Protein } \\
\hline Tinggi & 57 & $30(52,6 \%)$ & $27(47,4 \%)$ & $14.680(2,755-78,239)$ & 0,002 \\
\hline Normal & 117 & $24(20,5 \%)$ & $93(79,5 \%)$ & Ref & Ref \\
\hline \multicolumn{6}{|c|}{ Frekuensi pemberian } \\
\hline$>12$ kali & 48 & $46(95,8 \%)$ & $2(4,2 \%)$ & $302,143(42,894-2128,260)$ & $<0,001$ \\
\hline$\leq 12$ kali & 126 & $8(6,3 \%)$ & $118(93,7 \%)$ & Ref & Ref \\
\hline \multicolumn{6}{|c|}{ Ukuran_botol } \\
\hline$>180 \overline{\mathrm{ml}}$ & 18 & $17(94,4 \%)$ & $1(5,6 \%)$ & $9,220(0,334-254,403)$ & 0,189 \\
\hline$<180 \mathrm{ml}$ & 156 & $37(23,7 \%)$ & $119(76,3 \%)$ & Ref & Ref \\
\hline
\end{tabular}

dengan petunjuk pemberiaan susu yang tertera di panduan boks atau kaleng susu formula yang digunakan pengasuh subyek. Hal ini sulit dapat dikontrol sehingga peneliti tidak menganalisis faktor perancu tersebut. Pada penelitian ini juga tidak menganalisis dan membandingkan subyek dengan pemberiaan hanya susu formula dari usia 0 bulan dengan subyek yang diberikan campuran susu formula dengan ASI. Kelemahan lain penelitian ini dengan metode retrospektif yang kurang mencerminkan faktor penyebab kejadian status gizi lebih pada penggunaan susu formula sehingga diperlukan penelitian selanjutnya.

\section{Kesimpulan}

Didapatkan hubungan kadar tinggi protein berisiko 4 kali terjadi status gizi lebih. Hubungan pemberiaan susu formula $>12 \mathrm{kali} /$ hari dan ukuran botol susu $>180$ $\mathrm{ml}$ merupakan faktor yang memengaruhi kejadian status gizi lebih pada penelitian ini. 


\section{Daftar pustaka}

1. Sjarif D, Tanjung C. Susu formula bayi dan peraturan terkait. Dalam: Sjarif D, Lestari E, Mexitalia M, Nasar S, penyunting. Buku Ajar Nutrisi Pediatrik dan Penyakit Metabolik Jilid I. Jakarta: Badan Penerbit IDAI; 2014.h.102.

2. World Health Organization, UNICEF 2009. Acceptable medical reasons for using breastmilk substitutes. Geneva: WHO; 2009.

3. Kemenkes RI. Badan Penelitian dan Pengembangan Kesehatan. Kementerian Kesehatan RI tahun 2013. Jakarta: Riset Kesehatan Dasar; 2013.

4. Steven A, Keli M, Mohan P. A systematic review of controlled trials of lower protein or energy-containing infats formulas for use by healthy full-term infants. Adv Nutr 2015;6:178-88.

5. Koletzko B, von kries R, Closa R, dkk. Lower protein in infant formula is associated with lower weight up to age 2 year: a randomized clinical trial. Am J Clin Nutr 2009;89:1836-45.

6. Martina W, Veit G, Ricardo C, dkk. Lower protein content infant formula reduces BMI and obesity risk at school age: follow-up of a randomized trial. Am J Clin Nutr 2014;10:3945.

7. Sastroasmoro S, Ismail S. Dasar- dasar metodologi penelitian klinis. Edisi ke-5. Jakarta: Sagung Seto; 2014.h.130-43.

8. Weber M, Grote V, Closa-Monasterolo R, dkk. Lower protein in content in infant formula reduced BMI and obesity risk at school age: follow-up of a randomized trial. Am J Clin Nutr 2014;99:104-51.

9. Haschke F, Grathwohl D, Detzel P, dkk. Postnatal high protein intake can contribute to accelerated weight gain of infants and increased obesity risk. Nestle Nutr Inst Workshop Ser 2016:85:101-9.

10. Jie S, Bright I, Jing H, dkk. Infants BMI peak as a predictor of overweight and obesity at age 2 years in a Chinese communitybased cohort. BMJ Open 2017;7:e015122.

11. Bernadeta P, Bartloeij M, Stefanie M, dkk. Protein concentration in milk formula, growth and later risk of obesity: a systematic review. J Nutr 2016;146:551-64.

12. Koletzko B, Brands B, Poston L, dkk, Demmelmair H. Early nutrition programming of long-term health. Proc Nutr Soc 2012;71:371-8.

13. Sjarif D. Obesitas anak dan remaja. Dalam: Sjarif D, Lestari E, Mexitalia M, Nasar S, penyunting. Dalam: Buku Ajar Nutrisi Pediatrik dan Penyakit Metabolik Jilid I. Jakarta: Badan Penerbit IDAI;2014.h 236-4.

14. Puji L, Suyanto, Apoina K. Hubungan pratik pemberiaan susu formula dengan status gizi bayi usia 0-6 bulan di Kecamatan Semarang Timur Kota Semarang. JKM e-journal 2014;2: 339-48.

15. Charies TW, Asheley SSY, Russell LR, dkk. Bottel size and weight gain in formula-fed infants. Pediatrics 2016;138:e20154538. 